\title{
Epoetin Zeta
}

National Cancer Institute

\section{Source}

National Cancer Institute. Epoetin Zeta. NCI Thesaurus. Code C102571.

A recombinant form of the endogenous human cytokine erythropoietin (EPO) with erythropoiesis-stimulating activity. Similar to EPO, epoetin zeta binds to and activates erythropoietin receptors on the surface of committed erythroid progenitors in the bone marrow resulting in their proliferation and differentiation into functional erythrocytes. This may enhance red blood cell counts and hemoglobin levels. Epoetin zeta differs from other epoetins in its glycosylation profile. EPO is a glycosylated polypeptide primarily produced by renal peritubular cells and its synthesis is regulated by a serum oxygenation feedback mechanism. 